\title{
Who trusts the news media? Exploring the factors shaping trust in the news media in German-speaking Switzerland
}

Dorothee Arlt, University Bern, Institute of Communication and Media Studies, dorothee.arlt@ikmb.unibe.ch

\begin{abstract}
Although a decline of trust in the news media can be observed in many countries, in international comparison, Switzerland is still considered one of the countries with a relatively high level of media trust. Nevertheless, knowledge concerning the factors that promote and hinder media trust in Switzerland is still limited. Building on the research on media trust and media scepticism, this study investigates the effects of political orientation, political disenchantment, populist attitudes, and news exposure on media trust. The study uses survey data ( $N=1019,50 \%$ females, $50 \%$ males) on the Internet-using population of the German-speaking part of Switzerland, collected in June 2017. Examining media trust by assessing the characteristics of media coverage, two dimensions of trust were revealed: (1) trust in journalistic quality and (2) trust in the independence and impartiality of media coverage about political issues. Overall, the results demonstrate that the level of trust concerning these two dimensions is rather low, whereas the level of trust in journalistic quality is slightly higher than trust in the independence and impartiality of media coverage on political issues. Regarding possible explanations, the findings show that political disenchantment and populist attitudes, antiestablishment attitudes, and demand for people's sovereignty are negatively related to media trust, while belief in the homogeneity of the people is positively related. Moreover, the results reveal that exposure to news via public television in Switzerland is positively associated with trust in journalistic quality, while the use of special news websites is negatively associated with both dimensions of trust. The implications for future research on media trust are discussed.
\end{abstract}

\section{Keywords}

media trust, media scepticism, political disenchantment, populist attitudes, news exposure

\section{Introduction}

In many Western democracies, there is an ongoing public debate about the dramatic loss of public trust in the news media and journalism. Journalists are suspected of information concealment, news manipulation, or the production of "fake news." The mainstream media is even condemned as "propaganda machines" or "lying press." According to the latest 2017 Reuters Institute Digital News Report, more than half of the population (57\%) across all the 36 countries does not trust the media (Newman, Fletcher, Kalogeropoulos, Levy, \& Kleis Nielsen, 2017, p. 30). Also, in Switzerland, where the Swiss Radio and Television and printed newspapers are still the most important source for news, trust in the news media has slightly declined from $50 \%$ in 2016 to $46 \%$ in 2017 (Schranz,
Eisenegger, \& Udris, 2017). Hence, given that more than half the population in Switzerland's direct democracy does not trust the media, this erosion of trust is highly problematic, especially since most people in modern societies rely heavily on the news media to understand the major political and social issues of their countries, to observe other social systems such as politics, economy or science, and to reduce complexity (Kohring, 2004; Luhmann, 2001). Therefore, a certain level of trust in the news media is a crucial precondition for the functioning of modern democratic societies in terms of an informed participation in civic life and a building of trust in the institutions and activities that comprise the social and political spheres (Ardèvol-Abreu \& Gil de Zúñiga, 2017; Kohring, 2004). Hence, it is not surprising that communication science is current- 
ly intensifying its research on trust and distrust in the news media. In particular, media trust in the course of digitization has become a new issue (Blöbaum, 2016; Grosser, 2016) as recipients often place their trust in various new journalistic and non-journalistic actors online, of which some are accused of intentionally trying to undermine the recipients' trust in the traditional news media by disseminating misinformation and conspiracy theories online. However, despite the relevance of the issue, research on media trust is rather fragmented, unsystematic, and, used to be strongly focused on the United States; yet, nowadays also more studies from Israel and Germany exist. However, given the peculiarities of the American media system (Hanitzsch, Van Dalen, \& Steindl, 2018), it is difficult to draw conclusions on media trust in European countries based on U.S. studies, which is particularly true for Switzerland. Consequently, very little is known so far about trust versus mistrust in the news media in Switzerland (Schranz, Schneider, \& Eisenegger, 2016). Therefore, this study aims to investigate the level and dimensions of citizens' media trust in German-speaking Switzerland and to explore the factors shaping it. The remainder of this paper proceeds as follows: first, existing theoretical concepts of media trust are discussed as they will serve as the basis for the later operationalisation; second, previous studies regarding the factors influencing media trust and scepticism are reviewed to derive the paper's guiding hypotheses and research questions; third, data and measurements are introduced; and finally, the results are presented and critically discussed in the conclusion.

\section{Defining and Measuring Trust in News Media}

Although conceptualisations of trust can be found across a broad range of disciplines, including psychology (Rotter, 1967), organisation studies (Bachmann \& Zaheer, 2006; Mayer, Davis, \& Schoorman, 1995), sociology (Luhmann, 1968; Misztal, 1996), and media and communication sciences
(Bentele, 1994; Blöbaum, 2016; Kohring, 2004), there is still no commonly shared concept. However, despite the varied definitions, a number of key features of trust can be extracted from the existing research on trust (Blöbaum, 2016). ${ }^{1}$ While from a psychological perspective, trust describes "a mental state, an attitude" of individuals (Castelfranchi \& Falcone, 2000, p. 801), from a sociological perspective, trust refers to the relation between a trusting party, the trustor, and a party to be trusted, the trustee (Blöbaum, 2016), in which the trusting party is willing "to be vulnerable to the actions" of the trustee (Mayer, Davis, Schoorman, 1995, p. 712). Thus, in terms of media trust, it is not the interpersonal trust between individuals, but rather the system trust (Luhmann, 1968) or public trust (Bentele, 1994) that is relevant. According to Bentele (2015, p. 622), "Public trust can be defined as a process and an outcome of a publicly generated, communicative mechanism within which publicly perceptible individuals, organizations, and other social systems at as 'trust objects'. Public trust is generated within the public communication process in which 'trust subjects' attribute more or less trust to trust objects" (see also Bentele, 1994). In general, the trust relation is asymmetric as the trustee usually has a resource, for example, certain information, that the trustor does not have in the same amount (Jackob, 2012; Tsfati, 2002). Consequently, putting trust in the actions of the trustee enables the trusting party to reduce information complexity (Bentele, 1994; Luhmann, 1968) and to act in a situation of unlimited information and uncertainty (Blöbaum, 2016). In the context of media and communication, trust refers to the relations between journalists, media organ-

1 One reason why research on media trust is rather heterogeneous is that communication research on media trust initially emerged under the label of media credibility (Kohring \& Matthes, 2007). Consequently, the terms "media trust" and "media credibility" do not refer to totally different concepts, but have been used partly synonymously in previous research (e.g., Gaziano \& McGrath, 1986; Kiousis, 2001). 
isations, or journalism as a social system, which are the trust objects, and the recipients, who are the trust subjects (Blöbaum, 2016; Kohring, 2004). Therefore, media trust can be defined as recipients' willingness "to be vulnerable to the journalistic system's selection and communication of current information" (Grosser, 2016, p. 5) or "to be vulnerable to news content based on the expectation that the media will perform in a satisfactory manner" (Hanitzsch et al., 2018, p. 5). Thus, recipients put their trust in journalists, whom they expect "to put aside their political views and create unbiased news stories in accordance with the principles of 'objectivity,' 'fairness,' and 'clear separation of information and opinion'” (Ardèvol-Abreu \& Gil de Zúñiga, 2017 , p. 704 ) and in journalistic selectivity as "journalists selectively choose some information over other information" (Kohring \& Matthes, 2007, p. 239). Media distrust (Ladd, 2010) or media scepticism (Tsfati, 2002, 2003, 2010; Tsfati \& Peri, 2006), however, refer to the opposite concept as recipients have the impression "that journalists are not fair or objective in their reports" (Tsfati, 2003, p. 159) and that their selection decisions are inappropriate. Finally, with respect to the journalistic principles of fairness and balance, the concept of media (dis-)trust is closely related to the hostile media phenomenon, which describes peoples' tendency to perceive media coverage as biased against their own views (Gunther, 1992; Vallone, Ross, \& Lepper, 1985).

Given the variety of definitions and concepts, it is not surprising that trust in the media is operationalised in very different ways. One approach is to measure a diffuse, general level of media trust by asking recipients how much they trust the media or news (e.g., Ardèvol-Abreu \& Gil de Zúñiga, 2017; Fletcher \& Park, 2017; Jones, 2004; Lee, 2010; Tsfati \& Ariely, 2014). The problem with this approach, however, is that recipients have very different understandings of trust, which are not taken into account (Kohring, 2004). A second approach is to measure media trust with multiple items. For example, Kohring and Matthes (2007) measure people's trust in journalism with numerous items on four dimensions: trust in the selectivity of issues, trust in the selectivity of facts, trust in the accuracy of depictions, and trust in the journalistic assessment (see also Kohring, 2004). Likewise, Tsfati (2002, 2003), who examines media trust under the label "media scepticism," uses several items he initially adapted from Gaziano and McGrath's (1986) News Credibility Scale and Cappella and Jamieson's (1997) concept of "media cynicism." Moreover, single trust indicators such as impartiality or balance are at the core of hostile media research (Gunther, 1992; Vallone, Ross, \& Lepper, 1985).

\section{Predictors of Trust and Distrust in the Media}

The following section summarises the state of research on how recipients' characteristics are related to trust and distrust in the media. In order to systematise the sometimes very fragmented and contradictory state of research (Tsfati \& Cohen, 2013, p. 4), three dimensions of influence can be distinguished: political characteristics, media-related attitudes, individual behaviours, and individual characteristics.

\subsection{Political Characteristics}

From previous research, a whole series of connections between political characteristics and media trust can be derived. First, several studies found that a more conservative (Gronke \& Cook, 2007; Jones, 2004; Ladd, 2010) and right-wing political orientation (Livio \& Cohen, 2016; for example, for the German political party Alternative für Deutschland [AfD], Schultz, Jackob, Ziegele, Quiring, \& Schemer, 2017; Schindler et al., 2018), are associated with lower levels of media trust. Likewise, studies on the hostile media phenomenon found that perceptions of media bias are more strongly pronounced among conservatives than among democrats (e.g., Dalton, Beck, \& Huckfeldt, 1998; Huge \& Glynn, 2010; Lee, 2005). Hence, negative attitudes toward the news media result from recipients perceiving the media as being biased against their political predispositions. Second, 
scholars provide evidence that trust in the institutional news media is negatively related to political disenchantment (Schultz et al., 2017) and political cynicism (Carr, Barnidge, Lee, \& Tsang, 2014). In turn, satisfaction with the US president's job performance (Bennett, Rhine, Flickinger, \& Bennett, 1999) and trust in politics (Jones, 2004; Lee, 2010) are positively related to media trust. Likewise, media cynics - people that deeply distrust the established mainstream media - are strongly disappointed with politics and have doubts in the democratic system (Jackob, Schultz, Ziegele, Schemer, \& Quiring, 2017). Third, initial findings on the relation between populist attitudes and media trust demonstrate that people holding stronger populist attitudes show lower levels of media trust (Fawzi, 2016) and higher levels of media hostility (Schindler et al., 2018). This relation seems particularly plausible as "several researchers have suggested that populist actors often perceive mainstream media as part of the elite, as supporters of the established political powers, and thus advocates of the status quo" (Reinemann, Matthes, \& Sheafer, 2017, p. 389). Consequently, populists are quite likely to blame the mainstream media and journalists for what they perceive as unfair media coverage. Based on these findings, it can be summarised that right-wing political orientation, political disenchantment, and populist attitudes seem to diminish trust in the media, while trust in politics have an obverse effect. Therefore, the following hypothesis can be predicted:

\section{H1: Right-wing political orientation} $(H 1 a)$, political disenchantment (H1b), and populist attitudes (H1c) are negatively associated with media trust.

\subsection{News Exposure}

Presumably, it is no coincidence that the present debate concerning a decline of trust in the mainstream media corresponds with the digital media revolution. Media usage has become increasingly individualised, and many new information opportunities, such as social media, blogs, or alternative news websites, have emerged. At the same time, competition for the audience's attention is increasing, and the growing economic pressure on the established media has led to a loss of quality in many places. Consequently, the presumption suggests that media trust and distrust are related to people's individual information behaviours and media usage patterns. Although previous research supports this presumption, the direction of the relation, however, seems to vary strongly among different sources of information. Various studies reveal a positive relation between traditional news media use and media trust (Jackob, 2012; Schranz et al., 2016; Schultz et al., 2017; Tsfati, 2010; Tsfati \& Ariely, 2014). For example, Tsfati and Ariely (2014) found a positive relation between media trust and the use of television news and newspapers. Schranz et al. (2016) and Schultz et al. (2017) confirmed such a relation in particular for the use of public television, which in both Switzerland and Germany functions as a public institution. With respect to online media, empirical evidence is rather mixed. In the U.S. context, Johnson and Kaye (2014) found that using blogs and YouTube for information purposes was related negatively to trust in traditional news media, while using social networking sites (SNSs) for information purposes was related positively. By contrast, according to the findings of Schranz et al. (2016), social media use was associated negatively with media trust. Finally, the use of non-mainstream, alternative news websites seems to be positively related with media distrust (Schultz et al., 2017; Tsfati, 2010; Tsfati \& Peri, 2006). Based on these findings, the following two hypotheses regarding the relation between media use and media trust are predicted:

H2. Greater exposure to news through mainstream news media will be positively related to media trust.

H3. Greater exposure to news through social media (H3a) and non-mainstream, alternative media (H3b) will be negatively related to media trust. 


\subsection{Sociodemographic Characteristics} Regarding the relation between sociodemographic characteristics and media (dis-)trust, the empirical evidence is rather diverse. For example, two international comparative studies found that men trust the media significantly less than women (Schranz et al., 2016; Schultz et al., 2017; Tsfati \& Ariely, 2014). By contrast, various single-country studies found no relation between sex and media (dis-)trust (e.g., Bennett, Rhine, \& Flickinger, 2001; Gronke \& Cook, 2007; Lee, 2010; Livio \& Cohen, 2016). Findings on the effects of education and age are similarly contradictory. While some studies found that education was a negative predictor of media trust (Gronke \& Cook, 2007; Tsfati \& Ariely, 2014), others found a positive (Donsbach, Rentsch, Schielicke, \& Degen, 2009; Johnson \& Kaye, 2014) or even no effect (Jackob, 2012; Lee, 2010) of education. Similarly, most studies found that age had no effect (Bennett et al., 1999; Jackob, 2012; Lee, 2010; Livio \& Cohen, 2016; Tsfati \& Ariely, 2014). Thus, as previous studies have produced inconsistent findings on the effects of sociodemographic factors, the following research question is stated:

RQ1: How are sex, education, and age related to media trust?

\section{Methods}

\subsection{Data Collection and Sample}

A standardised online survey was conducted in June 2017 within the population of the German-speaking part of Switzerland among individuals older than 16. Respondents were recruited via an online access panel of a professional external panel provider, which is certified according to Global ISO 26362 and a member of the European Society for Opinion and Market Research (ESOMAR) and the German Society for Online Research (DGOF). Specific quotas regarding age, sex (crossed), and educational levels were imposed. Thus, the sample is roughly representative of the Internet-using population of the German-speaking part of Switzerland. Overall,
1019 people ( $50 \%$ females, $50 \%$ males) between 16 and 74 years old $(M=44$ years of age) took part in the study. Approximately $11 \%$ reported a low level of education, $49 \%$ a middle level, and $40 \%$ a high level.

\subsection{Measures}

Media trust. Considering the problems of measuring people's media trust with a single item (see Kohring, 2004), this study examines media trust with a total of 11 items adapted from previous studies on trust in journalism (e.g., Kohring \& Matthes, 2007), media credibility (Gaziano \& McGrath, 1986; Meyer, 1988), and media scepticism (Tsfati, 2002, 2003) on a fivepoint Likert scale (1 ["strongly disagree"] to 5 ["strongly agree"]), which were subsequently subjected to factor analysis. The Kaiser-Meyer-Oklin (KMO) statistic was 0.91 , indicating a strong validity for the factor analysis. The solution resulted in two distinct factors accounting for $63 \%$ of the total cumulative explained variance (Table 1). The first factor comprises seven items that examine to what extent recipients have the impression that the media meet journalistic quality criteria, such as credibility, balance, correctness or completeness; therefore, this factor was labelled trust in journalistic quality of media coverage about political issues. For further analysis, the items were summarised in an index $(M=2.8, S D=0.8$; Cronbach's $\alpha=.91)$, where the higher mean scores reflect a higher level of media trust. The second factor includes four items that reflect recipients' perception that the media coverage about political issues is influenced, biased, and one-sided. Due to the negative formulation of these items, they were recoded for further analysis and summarised in an index trust in independence and impartiality of media coverage about political issues $(M=2.6, S D=0.8$; Cronbach's $\alpha=.73)$.

Political dispositions. The respondents' political left-right orientation was assessed with one item asking respondents to place their own political position on a scale, where 1 meant "left" and 7 meant "right" $(M=4.1 ; S D=1.5)$. Respondents' disenchantment with politics was examined using indicators that have 
Table 1: $\quad$ Trust in the media coverage on political issues (factor analysis)

\begin{tabular}{|c|c|c|}
\hline Media coverage about political issues... & $\begin{array}{l}\text { Trust in journalistic quality of media } \\
\text { coverage about political issues }\end{array}$ & $\begin{array}{l}\text { Trust in independence and impartiality } \\
\text { of media coverage about political issues } \\
\text { (recoded) }\end{array}$ \\
\hline $\begin{array}{l}\ldots \text { is credible. } \\
\ldots \text { is balanced. } \\
\ldots \text { is carefully researched. } \\
\ldots \text { presents the facts as they are. } \\
\ldots \text { takes all essential aspects into account. } \\
\ldots \text { is neutral. } \\
\ldots \text { takes place from different angles. } \\
\ldots \text { is strongly influenced by politics and economy. } \\
\ldots \text { is determined by the political elite. } \\
\ldots \text { is distorted. } \\
\ldots \text { focuses only on negative aspects. }\end{array}$ & $\begin{array}{l}0.83 \\
0.82 \\
0.82 \\
0.81 \\
0.80 \\
0.76 \\
0.75\end{array}$ & $\begin{array}{l}0.82 \\
0.82 \\
0.69 \\
0.61\end{array}$ \\
\hline Eigenvalue & 4.86 & 2.03 \\
\hline
\end{tabular}

Note. Primary component analysis with varimax rotation; $62 \%$ explained variance; all factor loadings $>0.40 ; \mathrm{KM0}=0.91$.

been applied in previous research on political disengagement, such as perceived political non-influence and dissatisfaction with politics in terms of economic situation, government's performance, and democracy (Arzheimer, 2002; Wolling, 1999). Attitudes towards the possibility of having a political influence were examined using the following two statements on a five-point Likert scale (1 ["very little"] to 5 ["a lot"]), which were taken from the ESS 2014 questionnaire for Switzerland (FORS, 2014): "How much would you say the political system in Switzerland allows people like you to have a say in what the government does?" $(M=3.1 ; S D=1.1)$ and "How much would you say that the political system in Switzerland allows people like you to have an influence on politics?" $(M=3.0 ; S D=1.1)$. For further analysis, the items were recoded and entered in the index perceived non-influence on politics in Switzerland $(M=3.0, S D=1.0$; Cronbach's $\alpha=0.86$ ), where higher mean scores indicate that people are less convinced that they have an influence on politics in Switzerland. Respondents' dissatisfaction with politics was examined using the following three statements on a five-point Likert scale (1 ["extremely dissatisfied"] to 5 ["extremely satisfied"]), which were also taken from the ESS 2014 questionnaire for Switzerland (FORS, 2014): "On the whole, how satisfied are you with the present state of the economy in Switzerland?" $(M=3.5 ; S D=1.0)$, "Now thinking about the Switzerland government, how satisfied are you with the way it is doing its job?" ( $M=3.1 ; S D=1.0)$, "And on the whole, how satisfied are you with the way democracy works in Switzerland?" ( $M=3.6$; $S D=1.1$ ). For further analysis, the items were recoded and summarised in an index dissatisfaction with politics $(M=2.6$, $S D=0.9$; Cronbach's $\alpha=0.82$ ), where higher values reflect more positive attitudes and, thus, a greater political satisfaction. ${ }^{2}$ Finally, populist attitudes were examined using the nine-item version of the inventory developed in the National Centre of Competence in Research (NCCR) Democracy project (Schulz et al., 2017; Wirth et al., 2016). Based on this inventory, three dimensions of populist attitudes were assessed, each with three items on a five-point Likert scale (1 ["strongly disagree"] to 5 ["strongly agree"]): anti-establishment attitude $(M=3.5, \quad S D=0.9$;

2 To ensure that political disenchantment can actually be considered separately from media trust/distrust or whether both belong to the same "anti-establishment" concept an additional factor analysis using both the indicators for political disenchantment and for media trust was calculated (see Table 4 in the Appendix). The analysis extracted three dimensions, the two dimensions of media trust (see also Table 1) and a third one which comprised all indicators for political disenchantment. Thus, political disenchantment formed its own factor and therefore was considered as a predictor of media trust in this study. 
Cronbach's $\alpha=.66)$, demand for sovereignty of the people $(M=3.9, S D=0.9$; Cronbach's $\alpha=.82$ ), and belief in the homogeneity of the people $(M=2.9, S D=1.0$; Cronbach's $\alpha=.71){ }^{3}$

News exposure. To examine people's exposure to news through mainstream media, social media, and non-mainstream, alternative media, respondents were asked to indicate how often they use different information sources to inform themselves about political issues on an 8-point scale (0 ["never"] to 7 ["several times a day"]). ${ }^{4}$ Exposure to news through mainstream media was examined for the following five media outlets, and it did not matter whether respondents used them offline (on TV or as a printed version) or online (media library, website or via an app): public television news ( $M=3.0$; $S D=1.9)$, private television news $(M=2.3$; $S D=2.0)$, tabloids and commuter newspapers $(M=2.9 ; S D=2.2)$, local and national daily newspapers $(M=2.9 ; S D=1.9)$, and weekly newspapers and magazines

3 Anti-establishment attitude: "MPs in Parliament very quickly lose touch with ordinary people" $(M=3.7 ; S D=1.1)$; “The differences between ordinary people and the ruling elite are much greater than the differences between ordinary people" $(M=3.8 ; S D=1.1)$; "People like me have no influence on what the government does" $(M=3.2 ; S D=1.2)$; demand for sovereignty of the people: "The people should have the final say on the most important political issues by voting on them directly in referendums" $(M=4.0 ; S D=1.1)$; "The people should be asked whenever important decisions are taken" ( $M=4.0$; $S D=1.0$ ); "The people, not the politicians, should make our most important policy decisions" $(M=3.7 ; S D=1.1)$; belief in the homogeneity of the people: "Ordinary people are of good and honest character" $(M=3.1$; $S D=1.2)$; "Ordinary people all pull together" $(M=2.7 ; S D=1.2)$; "Although the Swiss are very different from each other, when it comes down to it they all think the same" $(M=2.8 ; S D=1.2)$.

4 Scale is based on the latest Reuters Institute Digital News Report 2017; 0 ("never"), 1 ("less than once a month"), 2 ("less than once a week"), 3 ("once a week"), 4 ("two to three days per week"), 5 ("four to six days per week"), 6 ("every day"), 7 ("several times a day”).
$(M=2.1 ; S D=1.7)$. Using political information through social media was measured for Facebook $(M=2.2 ; S D=2.5)$, Twitter $(M=0.7 ; S D=1.6)$, and YouTube $(M=1.7$; $S D=2.1)$. Finally, blogs $(M=0.7 ; S D=1.3)$ and special news websites, which are only available online $(M=0.9 ; S D=1.7)$ served as indicators for using political information from non-mainstream, alternative media.

\section{Results}

Taking a closer look at the descriptive results, it becomes apparent that just a marginal group of respondents perceives that the media coverage about political issues is independent and not influenced by politics and economy ( $9 \%$ agreement), the political elite ( $15 \%$ agreement), or distorted (24\% agreement). Likewise, only a minority has the impression that the media coverage is neutral ( $16 \%$ agreement), presents the facts as they are (20\% agreement), and is balanced (22\% agreement). Overall, the findings reveal that the level of media trust in the journalistic quality $(M=2.8, S D=0.8)$ of media coverage is slightly higher among the Swiss population than is their trust in the independence and impartiality of media coverage about political issues $(M=2.6$, $S D=0.8$ ) (see Table 2).

To explore further how media trust relates to sociodemographic characteristics, political dispositions, and news exposure, two hierarchical regression analyses were calculated using the two earlier extracted dimensions of media trust (see Table 1) as dependent variables. In the first step of the regressions, the control variables (age, sex, and education) were considered. In the second step, the various indicators for political dispositions were added as predictors. Finally, in the third step, variables on news exposure were included in the analysis. The results are presented in Table 3.

The results of the first step of the regressions show that, with one exception, media trust is not related to sociodemographic characteristics (see Table 3). Only younger people reported a higher level of trust in the independence and impartiality of 
Table 2: Descriptive results on distrust in the media coverage on political issues

\begin{tabular}{lccc}
\hline The media coverage on political issues... & M (SD) & Disagreement ${ }^{2}$ & Agreement $^{3}$ \\
\hline$\ldots$ is neutral. & $2.5(1.0)$ & $48 \%$ & $16 \%$ \\
$\ldots$ presents the facts as they are. & $2.8(1.0)$ & $42 \%$ & $20 \%$ \\
$\ldots$ is balanced. & $3.1(1.0)$ & $36 \%$ & $22 \%$ \\
$\ldots$ takes all essential aspects into account. & $2.9(1.0)$ & $36 \%$ & $25 \%$ \\
$\ldots$ is carefully researched. & $2.7(1.0)$ & $32 \%$ & $27 \%$ \\
$\ldots$ is credible. & $2.9(1.0)$ & $32 \%$ & $29 \%$ \\
$\ldots$ takes place from different angles. & $2.8(1.0)$ & $27 \%$ & $31 \%$ \\
Index: trust in journalistic quality of media coverage about political issues & $2.8(0.8)$ & & $94 \%$ \\
$\ldots$ is strongly influenced by politics and economy. (recoded) & $2.2(0.9)$ & $64 \%$ & $15 \%$ \\
$\ldots$ is determined by the political elite. (recoded) & $2.9(1.1)$ & $57 \%$ & $24 \%$ \\
$\ldots$ is distorted. (recoded) & $2.8(1.0)$ & $40 \%$ & $36 \%$ \\
$\ldots$ mainly focuses only negative aspects. (recoded) & $2.4(1.1)$ & $36 \%$ \\
Index: trust in independence and impartiality of media coverage about political issues & $2.6(0.8)$ & & 28 . \\
\hline
\end{tabular}

Note. 'Mean (M) and standard deviation (SD) on five-point Likert scale (1 ["strongly disagree"] to 5 ["strongly agree"]); ${ }^{2}$ points 1 and 2 on the scale. ${ }^{3}$ points 4 and 5 on the scale.

media coverage about political issues (age: $\beta=-0.11 ; p<.001)$. By contrast, the findings of the second step of the regressions reveal that media trust is strongly related to people's political dispositions. This becomes particularly apparent through the strong change of R-squared in both models. However, the effects of the single variables were extremely dissimilar. First, people's political orientation was not related to media trust; therefore, H1a must be rejected. Regarding the supposed negative relation between media trust and political disenchantment, this relation was strongly supported for people's trust in the journalistic quality, but not for trust in the independence and impartiality of media coverage about political issues. People perceiving themselves as having a low influence on politics $(\beta=-0.23 ; p<0.001)$ reported a lower level of trust in the journalistic quality of media coverage about political issues. Moreover, people who are more strongly dissatisfied with politics showed lower levels of trust in both journalistic quality and the independence and impartiality of media coverage (see Table 3). Looking at these findings together, $\mathrm{Hlb}$ is strongly supported as people who are disenchanted with politics show lower levels of media trust. With respect to the presumed negative influence of populist attitudes, the findings are mixed. For example, people's anti-establishment attitudes were the strongest predictor of trust in the indepen- dence and impartiality of media coverage about political issues $(\beta=-0.41 ; p<0.001)$, but showed no effect on trust in journalistic quality. Moreover, a strong demand for people's sovereignty was a negative predictor of media trust in both cases; however, it was significantly lower $(\beta=-0.10 ; p<.01)$. By contrast, the third dimension of populist attitudes tested here, the belief in the homogeneity of the people, was positively related to trust in the journalistic quality of media coverage about political issues $(\beta=0.16 ; p<.001)$. Thus, H1c was partly supported for anti-establishment attitude and the demand for people's sovereignty but must be rejected for the belief in the homogeneity of the people.

Regarding the relation between news exposure and media trust, the results of the third step of the regressions revealed a rather weak relation, as the R-squared changed just slightly, and the variables showed only isolated effects (see Table 3). Of the various variables tested for exposure to news through mainstream media, only one significant effect was found: People that are more frequently exposed to news via public television $(\beta=0.18$; $p<.001)$ reported a higher level of trust in the journalistic quality of media coverage about political issues. Consequently, H2 was confirmed only for one case. With respect to the presumed negative relation between exposure to news through social media and media trust, H3a must be re- 
Table 3: Hierarchical regression: influences of sociodemographic factors, political dispositions, and news exposure on media trust

\begin{tabular}{|c|c|c|c|c|}
\hline & \multicolumn{2}{|c|}{$\begin{array}{l}\text { Trust in journalistic quality of media } \\
\text { coverage about political issues }\end{array}$} & \multicolumn{2}{|c|}{$\begin{array}{c}\text { Trust in independence and impartiality } \\
\text { of media coverage about political } \\
\text { issues }\end{array}$} \\
\hline & $\beta$ & Sig. & $\beta$ & Sig. \\
\hline \multicolumn{5}{|l|}{ Block 1: Control Variables } \\
\hline Age (in years) & 0.05 & & -0.11 & ** \\
\hline Sex (men) & 0.03 & & 0.02 & \\
\hline Education (high) & 0.02 & & -0.02 & \\
\hline $\mathrm{R}^{2}$ & 0.00 & & 0.01 & \\
\hline \multicolumn{5}{|c|}{ Block 2: Control Variables + Political Predispositions } \\
\hline Age (in years) & 0.10 & ** & 0.00 & \\
\hline Sex (men) & -0.01 & & 0.03 & \\
\hline Education (high) & -0.03 & & -0.09 & $* *$ \\
\hline Political orientation ( $1=$ left; $7=$ right $)$ & -0.06 & & 0.01 & \\
\hline Perceived non-influence on politics (high) & -0.23 & $* * *$ & 0.03 & \\
\hline Dissatisfaction with politics (high) & -0.29 & $* * *$ & -0.07 & * \\
\hline Anti-establishment attitude (strong) & 0.01 & & -0.41 & $* * *$ \\
\hline Demand for people's sovereignty (strong) & -0.10 & $* *$ & -0.10 & $* *$ \\
\hline Belief in homogeneity of the people (strong) & 0.16 & $* * *$ & 0.02 & \\
\hline$R^{2}$ change & 0.23 & & 0.20 & \\
\hline \multicolumn{5}{|c|}{$\begin{array}{l}\text { Block 3: Control Variables + Political Predispositions + } \\
\text { News Exposure }\end{array}$} \\
\hline Age (in years) & 0.02 & & -0.02 & \\
\hline Sex (men) & -0.01 & & 0.03 & \\
\hline Education (high) & -0.05 & & -0.09 & ** \\
\hline Political orientation (1=left; $7=$ right) & -0.07 & * & 0.00 & \\
\hline Perceived non-influence on politics (high) & -0.20 & $* * *$ & 0.02 & \\
\hline Dissatisfaction with politics (high) & -0.26 & $* * *$ & -0.06 & \\
\hline Anti-establishment attitude (strong) & -0.01 & & -0.40 & $* * *$ \\
\hline Demand for people's sovereignty (strong) & -0.09 & * & -0.09 & * \\
\hline Belief in homogeneity of the people (strong) & 0.15 & $* * *$ & 0.02 & \\
\hline Public television news use & 0.18 & $* * *$ & 0.02 & \\
\hline Private television news use & -0.01 & & 0.07 & \\
\hline Tabloid and "commuter" newspapers use & 0.05 & & -0.01 & \\
\hline Local and national daily newspapers use & 0.00 & & 0.02 & \\
\hline Weekly newspapers and magazines use & 0.01 & & -0.06 & \\
\hline Facebook use & -0.06 & & -0.05 & \\
\hline Twitter use & 0.01 & & -0.02 & \\
\hline YouTube use & -0.01 & & 0.00 & \\
\hline Blog use & 0.10 & ** & 0.03 & \\
\hline Special News websites use & -0.09 & * & -0.10 & ** \\
\hline $\mathrm{R}^{2}$ change & 0.04 & & 0.02 & \\
\hline Total R² & 0.27 & & 0.23 & \\
\hline
\end{tabular}

Note. ${ }^{*} p<.05 ;{ }^{* *} p<.01 ;{ }^{* * *} p<.001$.

jected as no such effect could be found for Facebook, Twitter, or YouTube. Regarding the effect of using non-mainstream, alternative media on media trust, the evidence is mixed. The results showed that using a blog is positively related to people's trust in the journalistic quality of media cover- age about political issues $(\beta=0.19 ; p<.01)$. Thus, in the case of blogs, H3b must be rejected. By contrast, the findings revealed a strong relation between the exposure to news through special news websites on the Internet that provide alternative information, and trust in the media: people 
more frequently using such news websites to perceive information on political issues show lower levels of trust both in the quality $(\beta=-0.09 ; p<0.05)$ and in the independence and impartiality of media coverage about political issues $(\beta=-0.10 ; p<.01)$. Therefore, in the case of news exposure through special news websites, H3b was confirmed.

\section{Conclusion}

Although media trust in Switzerland is high compared to other countries, citizens' mistrust has risen by four percentage points in the last year (fög, 2017). However, with respect to the predicators and consequences of negative and sceptical attitudes towards the mainstream media, the majority of research now stems from the United States, Israel and Germany. Thus, despite the potential dangers of a declining media trust for the Swiss democracy, particularly as public broadcasts and the press are still the most important sources for news and political information for Swiss citizens, little is known about the dimensions, level, and predictors of media trust in Switzerland. Therefore, the present study explores media trust among Switzerland's German-speaking population.

Even though communication science has been dealing with media (dis-)trust and related phenomena like the hostile media phenomenon quite intensively for some years, no commonly shared concept of media trust exists. However, common to most conceptualisations is that media trust refers to the relation between the media and its audience, where the audience, as the trusting party, is willing to be vulnerable to news coverage and put their trust in an accurate, comprehensive, and neutral selection and presentation of information by the media and journalists (e.g., Ardèvol-Abreu \& Gil de Zúñiga, 2017; Grosser, 2016; Kohring \& Matthes, 2007). Based on this, many studies have examined trust in the media through an assessment of the characteristics and quality of media coverage that is the result of journalistic decision making and actions (Kohring,
2004; Kohring \& Matthes, 2007; Tsfati, 2002, 2003). Accordingly, in this study, media trust has been measured with multiple items to assess the characteristics of reporting on political issues (see Table 1). Thereby, two dimensions of media trust were extracted: (1) trust in the journalistic quality and (2) trust in the independence and impartiality of media coverage on political issues. Yet, with respect to the level of media trust, the findings show that it was rather low among the Swiss population on both dimensions. Regarding the question of who trusts the media, hypotheses regarding the relations of political characteristics and news exposure have been derived from previous research. To test these hypotheses, hierarchical regression analyses were applied to data from a quantitative online survey conducted in June 2017 with a quota sample of 1019 citizens from the German-speaking part of Switzerland.

Looking at the effects of people's political characteristics, the results strongly supported previous research that there is a significant relationship between political disenchantment and media trust; and yet, that they can be belong to different concepts (see also Table 4 in the Appendix). Perceptions of a minor influence on politics in Switzerland and dissatisfaction with politics are strongly related to lower levels of media trust. Furthermore, the findings strengthen the initial evidence that media trust is related to populist attitudes (Fawzi, 2016; Schindler et al., 2018); however, the direction and strength of this relation seem to vary along with the conceptualisation of populist attitudes. In this study, populist attitudes have been measured as three-dimensional (Schulz et al., 2017; Wirth et al., 2016), producing evidence on the relation of these three dimensions with media trust. While an anti-elitism attitude and preference for people's sovereignty were related negatively to media trust, belief in people's homogeneity was positively related. Thus, the findings in particular support the argumentation of Aalberg et al. (2017) that populists perceive institutional media as part of the political elite as an anti-elitism attitude turned out to be 
the strongest predictor for a low level of trust in the independence and impartiality of media coverage of political issues. Thus, people who view political elites as strongly distant from ordinary people and who view ordinary people as hardly influential on politicians show lower levels of trust in the independence and impartiality of media coverage of political issues.

The positive relation between mainstream media use and media trust that was found in previous studies (Schranz et al., 2016; Tsfati, 2010; Tsfati \& Ariely, 2014; Tsfati \& Cappella, 2003; Tsfati \& Cappella, 2005) was only supported for one case: People who more frequently use public television news report higher levels of trust in the journalistic quality of media coverage on political issues. Thus, this finding in particular supports the essential role of a distinct public broadcast - as is the case in Switzerland - in the debate regarding trust and mistrust in media. Other than expected, the use of social media for information reasons was not related to media trust. Finally, this study's findings strengthen the previous research that has shown that media trust is negatively related to the use of non-mainstream, alternative media (e.g., Tsfati, 2010; Tsfati \& Peri, 2006). In the present study, there is a consistent finding that a more frequent use of special news websites that provide alternative information on political issues is negatively related to trust both in the journalistic quality and in the independence and impartiality of media coverage about political issues. This result also strengthens the type of selective exposure that focusses on the medium as in the contemporary media environment people have the opportunity "to go online for information when they disagree with or do not trust the reportage in more mainstream outlets" (Stroud, 2017, p. 5). Overall, the results have revealed that media trust is mostly affected by political and populist attitudes and less affected by sociodemographic factors and media use. This finding underlines the general observation that the mistrust of the population is not directed specifically against the media, but more generally against social and political institutions and elites.
This study has some methodological weaknesses that must be acknowledged and addressed in future research. The first limitation relates to the use of cross-sectional data to examine the relation between political disenchantment, media use, and media trust; there are several reasons to expect that these three phenomena influence each other. This paper treated political disenchantment and news exposure as predictors of media trust; however, other studies examine media scepticism as a predictor of exposure (Tsfati \& Cappella, 2003, 2005) and political trust (Ariely, 2015) or media exposure as a predictor of political disenchantment (Maurer, 2003; Wolling, 1999, 2014). Consequently, so far, the question of the direction of causality between media trust, political disenchantment, and media use, and how they may affect each other over time, remains open. Therefore, in future research, panel surveys should be conducted to examine how these three concepts change over time. Particularly, the question of whether a negative downward spiral between a decline in media trust, political disenchantment, and news avoidance behaviours can be observed, and which factors may have the potential to counteract such a spiral, is of strong scientific and political interest. Second, this study uses data from an online survey conducted within the population of the German-speaking part of Switzerland; thus, the findings provide only partial insights. Therefore, future studies should examine the existence of media trust from a comparative perspective between the German-speaking, the French-speaking, and the Italian-speaking parts of Switzerland. Such an approach would provide an essential contribution for two reasons: 1) it allows for exploring the interplay between the media trust and political disenchantment in the different language regions, as well as the subsequent consequences for the direct democracy in Switzerland as a whole; 2) it offers the possibility not only to consider the influencing factors on media disenchantment at the individual level but also on the context level, as all three language regions represent linguistically segmented media markets that also dif- 
fer in the quality of the political reporting (fög, 2015, 2016).

\section{References}

Ardèvol-Abreu, A., \& Gil de Zúñiga, H. (2017). Effects of editorial media bias perception and media trust on the use of traditional, citizen, and social media news. Journalism \& Mass Communication Quarterly, 94(3) 703-724. doi:10.1177/1077699016654684

Ariely, G. (2015). Trusting the press and political trust: A conditional relationship. Journal of Elections, Public Opinion and Parties, 25(3), 351-367. doi:10.1080/17457289.201 4.997739

Arzheimer, K. (2002). Politikverdrossenheit. Bedeutung, Verwendung und empirische Relevanz eines politikwissenschaftlichen Begriffs. Wiesbaden: Westdeutscher Verlag. Bachmann, R., \& Zaheer, A. (2006). Handbook of trust research. Cheltenham, UK: Edward Elgar.

Bennett, S.E., Rhine, S. L., \& Flickinger, R. S. (2001). Assessing Americans' opinions about the news media's fairness in 1996 and 1998. Political Communication, 18(2), 163-182. doi:10.1080/105846001750322961

Bennett, S.E., Rhine, S. L., Flickinger, R. S., \& Bennett, L. L. M. (1999). "Video Malaise" revisited. Public trust in the media and government. Harvard International Journal of Press/Politics, 4(4), 8-23. doi:10.1177/1081180X9900400402

Bentele, G. (1994). Öffentliches Vertrauen normative und soziale Grundlage für Public Relations. In W. Ambrecht \& U. Zabel. (Eds., Normative Aspekte der Public Relations. Grundlagen und Perspektiven. Eine Einführung (pp. 131-158). Opladen: VS Verlag.

Bentele, G. (2015). Trust of publics. In W. Donsbach (Ed.), The concise encyclopedia of communication (pp. 622-623). Chichester: Wiley.

Blöbaum, B. (2016a). Key factors in the process of trust. On the analysis of trust under digital conditions. In B. Blöbaum (Ed.), Trust and communication in a digitized world: models and concepts of trust research (pp. 3-25). Cham: Springer.
Cappella, J. N., \& Jamieson, K. H. (1997). Spiral of cynicism: The press and the public good. New York et al.: Oxford University Press.

Carr, D. J., Barnidge, M., Lee, B. G., \& Tsang, S. J. (2014). Cynics and skeptics. Journalism \& Mass Communication Quarterly, 91(3), 452-470. doi:10.1177/1077699014538828

Castelfranchi, C., \& Falcone, R. (2000). Trust and control: A dialectic link. Applied Artificial Intelligence, 14(8), 799-823. doi:10.1080/08839510050127560

Dalton, R. J., Beck, P.A., \& Huckfeldt, R. (1998). Partisan cues and the media: Information flows in the 1992 Presidential election. The American Political Science Review, 92(1), 111-126. doi:10.2307/2585932

Donsbach, W., Rentsch, M., Schielicke, A.-M., \& Degen, S. (2009). Entzauberung eines Berufs. Was die Deutschen vom Journalismus erwarten und wie sie enttäuscht werden. Konstanz: UVK.

Fawzi, N. (2016). Low media trust=low political trust? Exploring the influence of disenchantment with the media on political attitudes. Paper presented at the $66^{\text {th }}$ ICA Conference, Fukuoka, Japan.

Fletcher, R., \& Park, S. (2017). The impact of trust in the news media on online news consumption and participation. Digital Journalism, 5(10), 1281-1299. doi:10.1080/ 21670811.2017.1279979

fög - Forschungsinstitut Öffentlichkeit und Gesellschaft/Universität Zürich (2015). Jahrbuch 2015 Qualität der Medien: Schweiz-Suisse-Svizzera. Hauptbefunde. Basel: Schwabe.

fög - Forschungsinstitut Öffentlichkeit und Gesellschaft/Universität Zürich (2016). Jahrbuch 2016 Qualität der Medien: Schweiz-Suisse-Svizzera. Hauptbefunde. Basel: Schwabe.

fög - Forschungsinstitut Öffentlichkeit und Gesellschaft/Universität Zürich (2017). 2017 Reuters Institute Digital News Report. Ergebnisse für die Schweiz. Zürich: Universität Zürich.

FORS (2014). ESS 2014 Questionnaire Switzerland. Retrieved from http://forscenter.ch/ de/our-surveys/international-surveys/european-social-survey/ess-fragebogen-pdf/

Gaziano, C., \& McGrath, K. (1986). Measuring the concept of credibility. Journalism \& 
Mass Communication Quarterly, 63(3), 451-462. doi:10.1177/107769908606300301

Gronke, P., \& Cook, T.E. (2007). Disdaining the media: The American public's changing attitudes toward the news. Political Communication, 24(3), 259-281. doi:10.1080/10584600701471591

Grosser, K. M. (2016). Trust in online journalism. Digital Journalism, 4(8), 1036-1057. doi:10.1080/21670811.2015.1127174

Gunther, A.C. (1992). Biased press or biased public? Attitudes toward media coverage of social groups. The Public Opinion Quarterly, 56(2), 147-167.

Hanitzsch, T., Van Dalen, A., \& Steindl, N. (2018). Caught in the nexus: A comparative and longitudinal analysis of public trust in the press. The International Journal of Press/Politics, 23(1), 3-23. doi:10.1177/1940161217740695

Huge, M., \& Glynn, C. J. (2010). Hostile media and the campaign trail: Perceived media bias in the race for governor. Journal of Communication, 60(1), 165-181. doi:10.1111/j.1460-2466.2009.01473.x

Jackob, N. (2012). Gesehen, gelesen - geglaubt? Warum die Medien nicht die Wirklichkeit abbilden und die Menschen ihnen dennoch vertrauen. München: Olzog.

Jackob, N., Schultz, T., Ziegele, M., Schemer, C., \& Quiring, O. (2017). Medienzyniker und Medienfans - Merkmale eines gespaltenen Publikums. In M. Haller (Ed.), Öffentliches Vertrauen in der Mediengesellschaft (pp. 118-138). Köln: Von Halem.

Johnson, T. J., \& Kaye, B. K. (2014). Credibility of social network sites for political information among politically interested internet users. Journal of Computer-Mediated Communication, 19(4), 957-974. doi:10.1111/ jcc4.12084

Jones, D. A. (2004). Why Americans don't trust the media: A preliminary analysis. The Harvard International Journal of Press/Politics, 9(2), 60-75. doi:10.1177/1081180x04263461

Kiousis, S. (2001). Public trust or mistrust? Perceptions of media credibility in the information age. Mass Communication and Society, 4(4), 381-403. doi:10.1207/ S15327825MCS0404_4
Kohring, M. (2004). Vertrauen in Journalismus: Theorie und Empirie. Konstanz: UVK.

Kohring, M., \& Matthes, J. (2007). Trust in news media: Development and validation of a multidimensional scale. Communication Research, 34(2), 231-252. doi:10.1177/0093650206298071

Ladd, J. M. (2010). Why Americans distrust the news media and how it matters. Princeton: Princeton University Press.

Lee, T.-T. (2005). The liberal media myth revisited: An examination of factors influencing perceptions of media bias. Journal of Broadcasting \& Electronic Media, 49(1), 4364. doi:10.1207/s15506878jobem4901_4

Lee, T.-T. (2010). Why they don't trust the media: An examination of factors predicting trust. American Behavioral Scientist, 54(1), 8-21. doi:10.1177/0002764210376308

Livio, O., \& Cohen, J. (2016). "Fool me once, shame on you": Direct personal experience and media trust. Journalism, 1-15. doi:10.1177/1464884916671331

Luhmann, N. (1968). Vertrauen: ein Mechanismus der Reduktion sozialer Komplexität. Stuttgart: Ferdinand Enke.

Luhmann, N. (2001). Soziale Systeme. Grundriss einer allgemeinen Theorie ( $9^{\text {th }}$ ed.). Frankfurt am Main: Suhrkamp.

Maurer, M. (2003). Politikverdrossenheit durch Medienberichte: Eine Paneluntersuchung. Konstanz: UVK.

Mayer, R. C., Davis, J.H., \& Schoorman, F.D. (1995). An integrative model of organizational trust. The Academy of Management Review, 20(3), 709-734. doi:10.2307/258792

Meyer, P. (1988). Defining and measuring credibility of newspapers: developing an index. Journalism Quarterly, 65(3), 567-574. doi:10.1177/107769908806500301

Misztal, B. A. (1996). Trust in modern societies: the search for the bases of social order. Cambridge: Polity Press.

Newman, N., Fletcher, R., Kalogeropoulos, A., Levy, D. A. L., \& Kleis Nielsen, R. (2017). Reuters Institute Digital News Report 2017. Retrieved from http://po.st/lfJFXh

Reinemann, C., Matthes, J., \& Sheafer, T. (2017). Citizens and populist political communication. In T. Aalberg, F. Esser, C. Reinemann, J. Strömbäck, \& C. de Vreese (Eds.), Populist political communication 
in Europe (pp. 381-393). New York, NY:

Routledge.

Rotter, J. B. (1967). A new scale for the measurement of interpersonal trust. Journal of Personality, 35(4), 651-665. doi:doi:10.1111/j.1467-6494.1967.tb01454.x

Schindler, J., Fortkord, C., Posthumus, L., Obermaier, M., Reinemann, C., Nayla, \& Fawzi. (2018). Woher kommt und wozu führt Medienfeindlichkeit? Zum Zusammenhang von populistischen Einstellungen, Medienfeindlichkeit, negativen Emotionen und Partizipation. Medien \& Kommunikationswissenschaft, 66(3), 283-301. doi:10.5771/1615-634X-2018-3-283

Schranz, M., Eisenegger, M., \& Udris, L. (2017). Switzerland. In N. Newman, R. Fletcher, A. Kalogeropoulos, D. A. L. Levy, \& R. Kleis Nielsen (Eds.), Reuters Institute Digital News Report 2017 (pp. 96-97): Reuters Institute for the Study of Journalism.

Schranz, M., Schneider, J., \& Eisenegger, M. (2016). Medienvertrauen - eine vergleichende Perspektive. fög - Forschungsinstitut Öffentlichkeit und Gesellschaft/Universität Zürich: Schwabe Verlag Basel.

Schultz, T., Jackob, N., Ziegele, M., Quiring, O., \& Schemer, C. (2017). Erosion des Vertrauens zwischen Medien und Publikum? Ergebnisse einer repräsentativen Bevölkerungsumfrage. Media Perspektiven (5), 246-259.

Schulz, A., Müller, P., Schemer, C., Wirz, D. S., Wettstein, M., \& Wirth, W. (2017). Measuring populist attitudes on three dimensions. International Journal of Public Opinion Research. doi:https://doi. org/10.1093/ijpor/edw037

Stroud, N. J. (2017). Selective exposure theories. In K. Kenski \& K. H. Jamieson (Eds.), The Oxford Handbook of Political Communication New York: Oxford University Press. Retrieved from http://www.oxfordhandbooks.com/view/10.1093/oxfordhb/9780199793471.001.0001/oxfordhb-9780199793471-e-009. doi:10.1093/ oxfordhb/9780199793471.013.009

Tsfati, Y. (2002). The consequences of mistrust in the news media: Media skepticism as a moderator in media effects and as a factor influencing news media exposure: University of Pennsylvania.
Tsfati, Y. (2003). Media skepticism and climate of opinion perception. International Journal of Public Opinion Research, 15(1), 65-82. doi:10.1093/ijpor/15.1.65

Tsfati, Y. (2010). Online news exposure and trust in the mainstream media: Exploring possible associations. American Behavioral Scientist, 54(1), 22-42. doi:10.1177/0002764210376309

Tsfati, Y., \& Ariely, G. (2014). Individual and contextual correlates of trust in media across 44 countries. Communication Research, 41(6), 760-782. doi:10.1177/0093650213485972

Tsfati, Y., \& Cappella, J. N. (2003). Do people watch what they do not trust? Exploring the association between news media skepticism and exposure. Communication Research, 30(5), 504-529. doi:10.1177/0093650203253371

Tsfati, Y., \& Cappella, J. N. (2005). Why do people watch news they do not trust? The need for cognition as a moderator in the association between news media skepticism and exposure. Media Psychology, 7(3), 251-271.

Tsfati, Y., \& Cohen, J. (2013). Perceptions of Media and media effects. The third-person effect, trust in media, and hostile media perceptions. In A. N. Valdivia \& E. Scharrer (Eds.), The International Encyclopedia of Media Studies: Media Effects/Media Psychology. Blackwell

Tsfati, Y., \& Peri, Y. (2006). Mainstream media skepticism and exposure to sectorial and extranational news mMedia: The case of Israel. Mass Communication and Society, 9(2), 165-187. doi:10.1207/ s15327825mcs0902_3

Vallone, R. P., Ross, L., \& Lepper, M. R. (1985). The hostile media phenomenon: Biased perception and perceptions of media bias in coverage of the Beirut massacre. Journal of Personality and Social Psychology, 49(3), 577-585. doi:10.1037/0022-3514.49.3.577

Wirth, W., Schemer, C., Schulz, A., Wettstein, M., Wirz, D., \& Müller, P. (2016). A Multi-dimensional measure to assess populist attitudes in the public in eight languages. Zurich, Switzerland: NCCR Democracy Working Paper No. 87. Retrieved from http://www.nccr-democracy.uzh.ch/publications/workingpaper/pdf/wp87.pdf 
Wolling, J. (1999). Politikverdrossenheit durch Massenmedien? Der Einfluss der Medien auf die Einstellungen der Bürger zur Politik. Opladen: Westdeutscher Verlag.

Wolling, J. (2014). Politikverdrossenheit als Folge von Unterhaltungsrezeption? In M. Dohle \& G. Vowe (Eds.), Politische Unterhaltung - Unterhaltende Politik. Forschung zu Medieninhalten, Medienrezeption und Medienwirkungen. Köln: Herbert von Halem.

\section{Appendix}

Table 4: Trust in the media coverage on political issues and political disenchantment (factor analysis)

\begin{tabular}{|c|c|c|c|}
\hline & $\begin{array}{c}\text { Trust in journalistic } \\
\text { quality of media } \\
\text { coverage about } \\
\text { political issues }\end{array}$ & $\begin{array}{l}\text { Indicators } \\
\text { for political disen- } \\
\text { chantment }\end{array}$ & $\begin{array}{l}\text { Trust in indepen- } \\
\text { dence and impartial- } \\
\text { ity of media cover- } \\
\text { age about political } \\
\text { issues (recoded) }\end{array}$ \\
\hline $\begin{array}{l}\text { Media coverage about political issues... } \\
\ldots \text { is carefully researched. } \\
\ldots \text { is balanced. } \\
\ldots \text { is credible. } \\
\ldots \text { presents the facts as they are. } \\
\ldots \text { takes all essential aspects into account. } \\
\ldots \text { takes place from different angles. } \\
\ldots \text { is neutral. }\end{array}$ & $\begin{array}{l}0.80 \\
0.80 \\
0.79 \\
0.78 \\
0.77 \\
0.75 \\
0.75\end{array}$ & & \\
\hline $\begin{array}{l}\text { On the whole, how satisfied are you with the way democracy works } \\
\text { in Switzerland? }\end{array}$ & & 0.78 & \\
\hline $\begin{array}{l}\text { How much would you say the political system in Switzerland allows } \\
\text { people like you to have a say in what the government does? }\end{array}$ & & 0.76 & \\
\hline $\begin{array}{l}\text { How much would you say that the political system in Switzerland } \\
\text { allows people like you to have an influence on politics? }\end{array}$ & & 0.74 & \\
\hline $\begin{array}{l}\text { Now thinking about the Switzerland government, how satisfied are } \\
\text { you with the way it is doing its job? }\end{array}$ & & 0.74 & \\
\hline $\begin{array}{l}\text { And on the whole, how satisfied are you with the present state of } \\
\text { the economy in Switzerland? }\end{array}$ & & 0.70 & \\
\hline $\begin{array}{l}\text { Media coverage about political issues... } \\
\ldots \text { is strongly influenced by politics and economy. } \\
\ldots \text { is determined by the political elite. } \\
\ldots \text { is distorted. } \\
\ldots \text { focuses only negative aspects. }\end{array}$ & & & $\begin{array}{l}0.82 \\
0.81 \\
0.68 \\
0.62\end{array}$ \\
\hline Eigenvalue & 5.95 & 2.07 & 1.94 \\
\hline
\end{tabular}

Note. Primary component analysis with varimax rotation; $62 \%$ explained variance; all factor loadings $>0.40 ; \mathrm{KMO}=0.90$. 
